Jurnal Pemberdayaan: Publikasi Hasil Pengabdian kepada Masyarakat

Vol. 2, No. 3, Desember 2018, Hal. 543-548

ISSN: 2088 4559; e-ISSN: XXXX-XXXX

DOI:

\title{
PEMBERDAYAAN MASYARAKAT DESA KANEKES PADA PROGRAM KEBERSIHAN DAN KESEHATAN UNTUK MENDUKUNG WISATA ADAT BADUY
}

\author{
Iis Wahyuningsih dan Samsul Alam \\ Universitas Ahmad Dahlan, Kampus 3, Jl. Prof. Dr. Supomo, Janturan, Yogyakarta \\ Email: iis.wahyuningsih@pharm.uad.ac.id
}

\begin{abstract}
ABSTRAK
Desa Kanekes mempunyai potensi wisata yang unik dengan keberadaan suku Baduy didalamnya. Namun, ditemukan permasalahan masih kurangnya kesadaran masyarakat akan kebersihan. Program pengabdian yang dilakukan dalam bentuk KKN ini bertujuan meningkatkan peran serta masyarakat desa Kanekes dalam kebersihan dan kesehatan. Metode yang digunakan berupa pendidikan masyarakat, difusi ilmu pengetahuan dan teknologi, serta praktek langsung/pendampingan. Dampak program pada masyarakat berupa 1) peningkatan kebersihan diri dan lingkungan, 2) peningkatan ketrampilan membuat the daun coklat, 3) tersedianya $1 \mathrm{MCK}$ umum, 4) peningkatan pengetahuan akan bahaya narkoba.
\end{abstract}

Kata kunci: Kanekes, kebersihan, kesehatan

\section{ABSTRACT}

Kanekes Village has unique tourism potential with the existence of the Baduy tribe in it. However, problems are still found in the lack of public awareness of cleanliness. The service program carried out in the form of KKN aims to increase the participation of the Kanekes village community in environmental and health hygiene. The method used is in the form of community education, diffusion of science and technology, as well as direct practice / assistance. The impact of the program on the community in the form of 1) increased self-esteem and the environment, 2) improvement in cocoa leaf making skills, 3) availability of 1 public MCK, 4) increased knowledge of the dangers of drugs.

Keywords: Kanekes, hygiene, health 


\section{PENDAHULUAN}

Jumlah penduduk Desa Kanakes, Kecamatan Leuwidamar, Kabupaten Lebak, Provinsi Banten pada Tahun 2017 mencapai 11.699 jiwa, dengan komposisi 5.788 perempuan dan 5.911 laki-laki. Dengan jumlah KK 3.413. Keunikan masyarakat Baduy, Desa Kanekes adalah sangat taat dalam memegang adat istiadat yang telah diwariskan secara turun temurun dan relatif menutup diri dari pengaruh luar yang mereka anggap akan merusak atau bertentangan dengan tata nilai dan adat istiadat mereka. Hasilnya masyarakat Baduy Desa Kanekes mampu bertahan dalam kurun waktu yang cukup lama.

Salah satu keunikan masyarakat Baduy yaitu menjadi pusat obat-obatan organik tradisional yang berada di sekeliling hutan atau Wanatamba. Masyarakat Desa Kanekes masyarakat agraris. Suatu kewajiban bagi masyarakat Baduy Desa Kanekes yang telah berkeluarga adalah menanam padi pada lahan kering (Huma). Sistem pertanian masyarakat Baduy Desa Kanekes dikenal dengan Sistem Keorganikannya. Baik pada pupuk, pembasmi gulma maupun pembasmi serangga menggunakan vegetasi yang tersedia di sekitar mereka. Siklus pertanian dari mulai menanam, memanen, pengeringan sampai dimasukan kedalam lumbung padi (leuit) dilakukan dengan proses alami. Ada yang unik pada masyarakat Baduy saat melakukan penanaman padi diiringi oleh acara ritual Angklung Buhun yaitu kesenian tradisional terbuat dari bambu dengan menabuh angklung. Disamping itu masyarakat Baduy Desa Kanekes juga berkebun. Hasil perkebunan pada masyarakat Baduy adalah durian, petai, picung, aren, muncang, binglu, kecapi, ranji, jatake, kupa, duku, pisitan, kaweni, limus, manggu, tiwu endog, hiris, kumili, dll.

Selain potensi di atas desa Kanekes juga mempunyai beberapa permasalahan, diantaranya :

1) lingkungan yang masih kurang bersih sehingga kesadaran warga akan kebersihan masih harus ditingkatkan. Padahal desa Kanekes sering mendapat tamu wisata yang akan berkunjung ke suku Baduy.

2) Beberapa warga masih mempuyai kebiasaan mandi dan mencuci di sungai

3) Banyak tanaman coklat yang hanya dimanfaatkan buahnya saja, padahal daunnya juga mempunyai potensi untuk kesehatan.

4) Banyaknya wisatawan ke suku Baduy baik domestik maupun mancanegara dapat membawa dampak mudah masuknya pengaruh buruk, seperti penyalahgunaan narkoba. 
Dengan latar belakang beberapa permasalah yang ditemukan di atas, maka program KKN UAD kali ini bertujuan meningkatkan peran serta masyarakat desa Kanekes dalam kebersihan lingkungan dan kesehatan.

\section{METODE}

Untuk mencapai tujuan yang diharapkan, program KKN Universitas Ahmad Dahlan (UAD) di Desa Kanekes, dilakukan dengan mengajak masyarakat melalui metode pendidikan masyarakat, difusi ilmu pengetahuan dan teknologi, serta praktek langsung/pendampingan. Waktu pelaksanaan program dari tanggal 10 Agustus-10 September 2018. Ringkasan metode pelaksanaan beserta jam kerja efektif mahasiswa (JKEM) tersaji pada Tabel I.

Tabel 1. Metode, Kegiatan dan JKEM

\begin{tabular}{|c|c|c|c|}
\hline No & Metode & Kegiatan & JKEM \\
\hline \multirow[t]{3}{*}{1} & \multirow{3}{*}{$\begin{array}{l}\text { Pendidikan } \\
\text { masyarakat }\end{array}$} & Penyuluhan PHBS & $1 \times 100 ”$ \\
\hline & & Penyuluhan dan Pelatihan Hidup Sehat & $1 \mathrm{x} 100 "$ \\
\hline & & Penyuluhan bahaya narkoba & $1 \times 100 "$ \\
\hline 2 & Difusi iptek & $\begin{array}{l}\text { Pelatihan pembuatan bros dari barang } \\
\text { bekas }\end{array}$ & $1 \times 100 "$ \\
\hline \multirow[t]{3}{*}{3} & Praktek & & \\
\hline & & $\begin{array}{l}\text { Penyelenggaraan pembuatan teh dari daun } \\
\text { kakao }\end{array}$ & $1 \times 200 ”$ \\
\hline & & $\begin{array}{l}\text { Pendampingan pembuatan MCK } \\
\text { Gerakan masjid sehat }\end{array}$ & $1 \times 200 ”$ \\
\hline
\end{tabular}

\section{HASIL, PEMBAHASAN, DAN DAMPAK}

Penyuluhan PHBS dilakukan pada Rabu, 05 September 2018. Kegiatan ini dilaksanakan bersama warga. Materi yang disampaikan pada penyuluhan ini adalah gerakan $3 \mathrm{M}$, yang dimaksudkan agar warga semakin menjaga lingkungannya.

Penyuluhan dan Pelatihan Hidup sehat. Kegiatan ini dilaksanakan pada Senin, 27 Agustus 2018. Kegiatan ini ditujukan kepada seluruh siswa/i MI \& MTS yang ada di Kp. Cicakal Girang, desa Kanekes. Kegiatan ini meliputi penyuluhan tentang pentingnya 
menjaga kesehatan tubuh dan lingkungan, dengan rajin menggosok gigi, mencuci tangan dan selalu buang sampah pada tempatnya.

Gerakan Masjid Sehat, kegiatan ini dilaksanakan pada Minggu, 12 Agustus 2018. Kegiatan ini dilakukan bersama mahasiswa KKN dan masyarakat. Kegiatan ini bertujuan untuk mengajak dan menyadarkan masyarakat betapa pentingnya menjaga kebersihan masjid. Gambaran beberapa kegiatan tersaji pada Gambar 1.

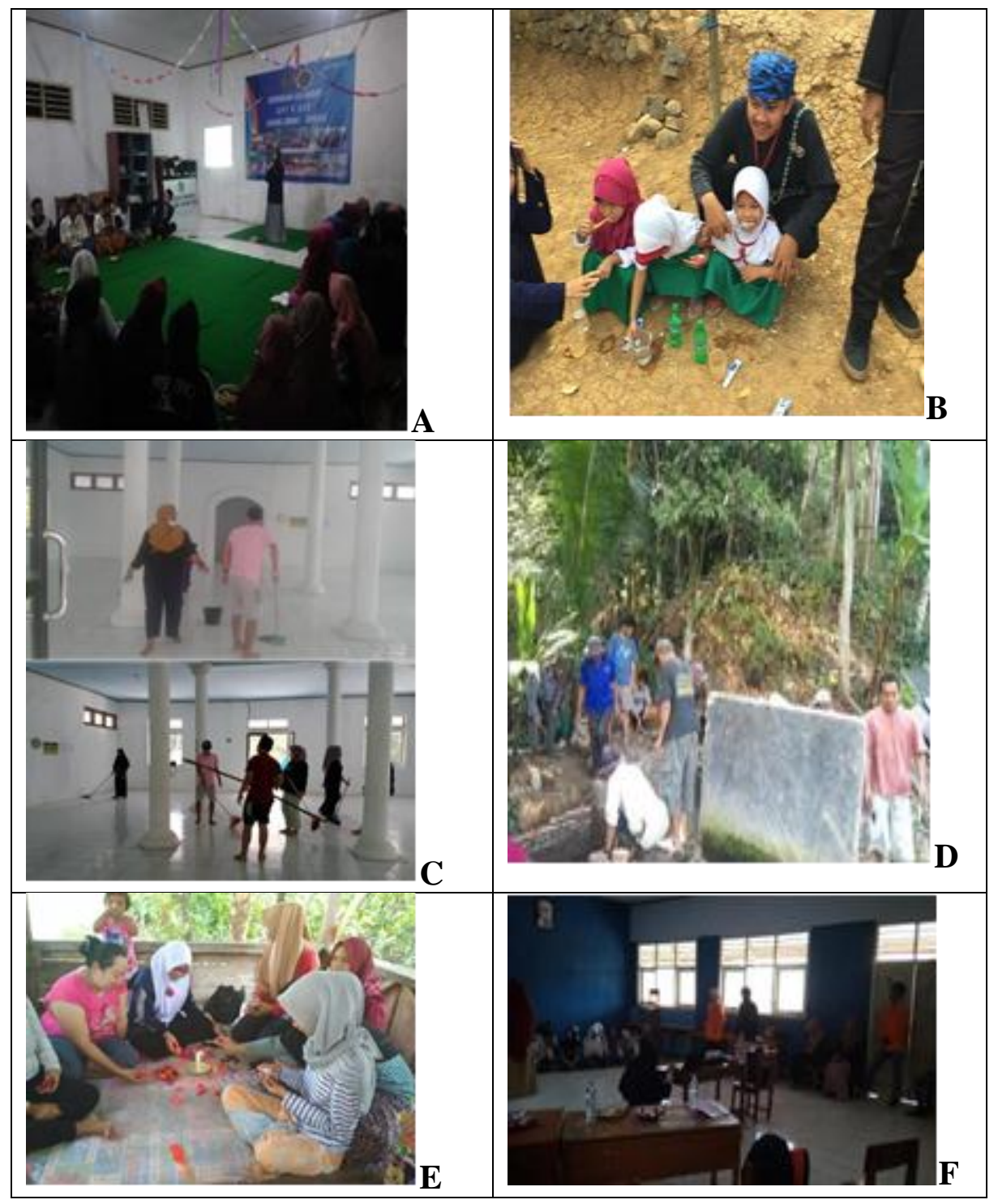

Gambar 1. A) penyuluhan PHBS pada warga B) Penyuluhan PHBS pada siswa sekolah, C) Gerakan masjid bersih, D) pendampingan pembuatan tempat MCK umum, E) pembutan bros dari kain perca, F) penyuluhan bahaya narkoba 
Kegiatan membangun MCK bersama warga sekitar untuk mempermudah masyarakat sekitar dalam pemanfaatan air bersih dari mataair di tempat tersebut. Kegiatan ini dilakukan pada tanggal 31 Agustus 2018 dan 02 September 2018.

Memberikan dan melakukan pelatihan membuat pin dari kain perca kepada ibuibu yang dilakukan pada tanggal 20 dan 22 Agustus 2018. Kegiatan ini bertujuan untuk membantu ibu-ibu sekitar menambah penghasilan sampingan.

Penyuluhan Kesehatan bersama Puskesmas Bojongmenteng yang dilakukan di SMK Muhamadiyah Pertanian Leuwidamar tentang bahayanya narkoba untuk remaja. Kegiatan ini bersasaran kepada siswa-siswi SMK Muhammadiyah Pertanian Leuwidamar. Kegiatan ini dilaksanakan pada tanggal 04 September 2018.

Dari semua program KKN yang telah dijalankan semua berlangsung dengan baik karena didukung oleh peran serta masyarakat. Pentingnya peran serta masyarakat dalam pembangunan kesehatan, telah diakui oleh semua pihak. Hasil pengamatan, pengalaman lapangan sampai peningkatan cakupan program yang dikaji secara statistik, semuanya membuktikan bahwa peran serta masyarakat amat menentukan terhadap keberhasilan, kemandirian dan kesinambungan pembangunan kesehatan (Anonim, 2013a).

Kesehatan merupakan kebutuhan setiap orang, oleh karena itu kesehatan seharusnya tercermin dalam semua kegiatan setiap orang. Menurut Anonim (2013b) peran serta masyarakat dalam bidang kesehatan diarahkan melalui 3 kegiatan utama yakni :

1) Kepemimpinan, yaitu melakukan intervensi kepemimpinan baik formal maupun informal, dari tingkat atas sampai tingkat terbawah.

2) Pengorganisasian, yaitu melakukan intervensi 'community development' di bidang kesehatan pada setiap kelompok masyarakat.

3) Pendanaan, yaitu mengembangkan sumber dana masyarakat untuk membiayai berbagai bentuk kegiatan di bidang kesehatan, dari tingkat promotif, preventif, kuratif maupun rehabilitatif. Wujudnya berupa dana sehat yang merupakan kunci 'sustainabilitas' kegiatan kesehatan kelompok masyarakat yang bersangkutan.

Dampak program KKN ini pada masyarakat berupa 1) peningkatan kebersihan diri dan lingkungan, 2) peningkatan ketrampilan membuat the daun coklat , 3) tersedianya 1 MCK umum,4) peningkatan ketrampilan membuat bros dari kain perca, 5) peningkatan pengetahuan akan bahaya narkoba. 


\section{SIMPULAN}

Dengan berbagai kegiatan dalam program KKN, mahasiswa UAD telah berupaya untuk meningkatkan peran serta masyarakat desa Kanekes dalam kebersihan lingkungan dan kesehatan, yang secara tidak langsung akan mendukung potensi wisata adat Baduy di desa Kanekes.

\section{DAFTAR PUSTAKA}

http://e-medis.blogspot.com/2013/06/tujuan-penggerakan-peran-masyarakat.html diakses 19 Januari 2019

http://e-medis.blogspot.com/2013/06/pentingnya-peran-serta-masyarakat.html diakses 19 Januari 2019.

\section{UCAPAN TERIMAKASIH}

Terimakasih pada semua warga, tokoh masyarakat desa Kanekes dan Universitas Muhammadiyah Tangerang atas kerjasama yang baik, sehingga kegiatan KKN UAD dapat berjalan dengan lancar. 